University of South Florida

DIGITAL COMMONS

Digital Commons @ University of

@ UNIVERSITY OF SOUTH FLORIDA

South Florida

\title{
Temperature Anomalies in the Lower Suwannee River and Tidal Creeks, Florida, 2005
}

\author{
Ellen A. Raabe \\ Elzbieta Bialkowska-Jelinska \\ University of Memphis, elzbieta@usf.edu
}

Follow this and additional works at: https://digitalcommons.usf.edu/geo_studpub

Part of the Earth Sciences Commons

\section{Scholar Commons Citation}

Raabe, Ellen A. and Bialkowska-Jelinska, Elzbieta, "Temperature Anomalies in the Lower Suwannee River and Tidal Creeks, Florida, 2005" (2007). School of Geosciences Student Publications. 83.

https://digitalcommons.usf.edu/geo_studpub/83

This Technical Report is brought to you for free and open access by the School of Geosciences at Digital Commons @ University of South Florida. It has been accepted for inclusion in School of Geosciences Student Publications by an authorized administrator of Digital Commons @ University of South Florida. For more information, please contact digitalcommons@usf.edu. 


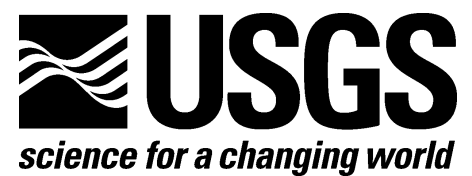

\section{Temperature anomalies in the Lower Suwannee River and tidal creeks, Florida, 2005}

By Ellen A. Raabe and Elzbieta Bialkowska-Jelinska

Open-File Report 2007-1311

U.S. Department of the Interior U.S. Geological Survey 


\section{U.S. Department of the Interior DIRK KEMPTHORNE, Secretary}

\section{U.S. Geological Survey \\ Mark D. Myers, Director}

U.S. Geological Survey, Reston, Virginia 2007

Revised and reprinted: 2007

For product and ordering information:

World Wide Web: http://www.usgs.gov/pubprod

Telephone: 1-888-ASK-USGS

For more information on the USGS - the Federal source for science about the Earth, its natural and living resources, natural hazards, and the environment:

World Wide Web: http://www.usgs.gov

Telephone: 1-888-ASK-USGS

Suggested citation:

Raabe, E.A., and Bialkowska-Jelinska, E., 2007, Temperature anomalies in the Lower Suwannee River and tidal creeks, Florida, 2005: U.S. Geological Survey Open-File Report 2007-1311, 28 p.

Any use of trade, product, or firm names is for descriptive purposes only and does not imply endorsement by the U.S. Government. This report is preliminary and has not been reviewed for conformity with the U.S. Geological Survey editorial standards. Not to be used for navigation.

Although this report is in the public domain, permission must be secured from the individual copyright owners to reproduce any copyrighted material contained within this report. 


\section{Contents}

Abstract

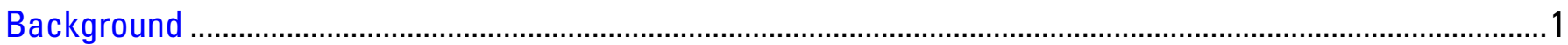

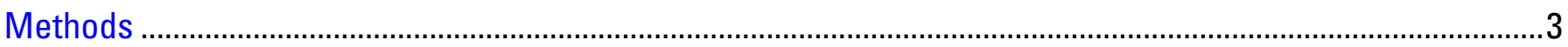

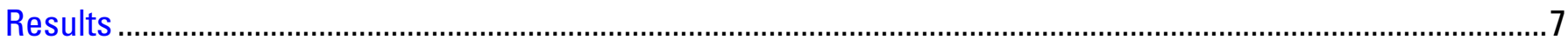

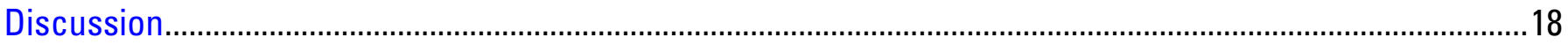

Products

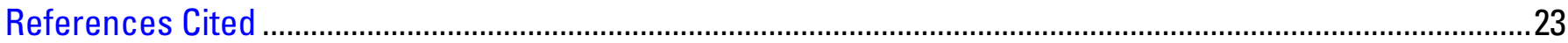

\section{Figures}

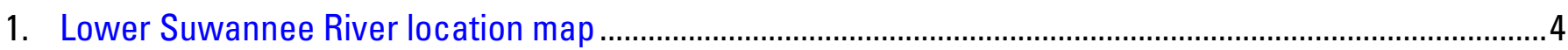

2. Interactive Map Lower Suwannee Rivers and tidal creeks ..........................................................................

3. Temperature anomalies derived from TIR imagery at Manatee Springs ......................................................

4. Temperature anomalies derived from TIR imagery at Dead Boy Creek .......................................................9

5. Temperature anomalies derived from TIR imagery at Spring Creek.......................................................11

6. Temperature anomalies derived from TIR imagery at Clark Creek ............................................................12

7. Temperature anomalies derived from TIR imagery at Ericson Creek ........................................................13

8. Temperature anomalies derived from TIR imagery at Big Trout Creek .....................................................14

9. Temperature anomalies derived from TIR imagery at McCormick Creek ...................................................17

10. Temperature anomalies derived from TIR imagery at Town of Suwannee ................................................19

11. Temperature anomalies derived from TIR imagery at Sanders Creek .......................................................20

\section{Tables}

1. Calibration of image values with surface temperature values.

\section{Photos}

1. Herbaceous wetland vegetation was associated with the seep on Gopher River .......................................7

2. Spring Creek runs through a small hammock before entering the tidal creek ...........................................10

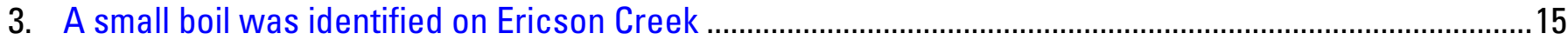

4. A small boil feeds a tadpole-shaped feature on Big Trout Creek...............................................................

5. Sawgrass surrounds Stillwater Pond ................................................................................................... 16

6. Exposed limestone lines this section of McCormick Creek ........................................................................18

7. Oyster bars were associated with temperature anomalies on Johnson Creek............................................21 


\title{
Temperature anomalies in the Lower Suwannee River and tidal creeks, Florida, 2005
}

\author{
By Ellen A. Raabe and Elzbieta Bialkowska-Jelinska
}

\begin{abstract}
Temperature anomalies in coastal waters were detected with Thermal Infrared imagery of the Lower Suwannee River (LSR) and nearshore tidal marshes on Florida's Gulf Coast. Imagery included 1.5-m-resolution day and night Thermal Infrared (TIR) and 0.75-mresolution Color Infrared (CIR) imagery acquired on 2-3 March 2005. Coincident temperature readings were collected on the ground and used to calibrate the imagery. The Floridan aquifer is at or near the land surface in this area and bears a constant temperature signature of $\sim 22$ degrees Celsius. This consistent temperature contrasts sharply with ambient temperatures during winter and summer months. Temperature anomalies identified in the imagery during a late-winter cold spell may be correlated with aquifer seeps. Hot spots were identified as those areas exceeding ambient water temperature by 4 degrees Celsius or more. Warm-water plumes were also mapped for both day and night imagery. The plume from Manatee Spring, a first-order magnitude spring, influenced water temperature in the lower river. Numerous temperature anomalies were identified in small tributaries and tidal creeks from Shired Island to Cedar Key and were confirmed with field reconnaissance. Abundant warm-water features were identified along tidal creeks south of the Suwannee River and near Waccasassa Bay. Features were mapped in the tidal creeks north of the river but appear to be less common or have lower associated discharge. The imagery shows considerable promise in mapping coastal-aquifer seeps and understanding the underlying geology of the region. Detection of seep locations may aid research in groundwater/surfacewater interactions and water quality, and in the management of coastal habitats.
\end{abstract}

\section{Background}

\section{Lower Suwannee River}

The Lower Suwannee River on Florida's Gulf Coast is entrenched in a limestone channel. The area is characterized by karstic, water-bearing limestone, sand ridges, numerous springs, and extensive forested floodplain (Rupert, 1988; Rupert, 1991; Vernon, 1951). The Floridan aquifer is generally unconfined, and the potentiometric surface is at or near the land surface in this area (Crane, 1986). Groundwater flows in two directions in the lower Suwannee River Basin (SRB): toward the river and toward the Gulf of Mexico (Crane, 1986). Despite the lack of barrier islands or an embayment common to estuaries, the coastal water body functions much like a classic estuary: low wave energy, shallow water, extensive tidal marsh, and dilution of marine salinities with abundant freshwater influx (Orlando, 1993; Siegel et al., 1996; Wolfe, 1990).

Economic interests in the basin, water supply, and many species and their habitats are linked to river discharge and flow from the Floridan aquifer. Detecting the location of seeps can aid in understanding geologic structure and influence (Shaban et al., 2005), groundwater/surface-water interactions (Tillis, 2000), habitat and species distribution, and water quality (Katz et al., 1999; Roseen et al., 2002; Scott, 2006). A population of Gulf of Mexico sturgeon relies on freshwater 
seeps within the Lower Suwannee riverbed for thermal regulation of water temperature and benthic food resources (Chapman and Carr, 1995; Carr et al., 1996; Brooks and Sulak, 2004). The Lower Suwannee has been identified as important Florida manatee habitat (Packard and Wetterquist, 1986). Wetlands and forested floodplains may be negatively impacted by decreased groundwater discharge (Wolfe, 1990; Darst et al., 2002). Even brief periods of drought can alter species composition in Suwannee tidal wetlands (Clewell, 2000).

\section{Floridan aquifer}

The complex interactions between surface water and groundwater in the lower SRB and estuary play a significant role in the ecology of the region (Edwards and Raabe, 2004). The delayed recovery of Suwannee discharge following a statewide drought in the 1950s exemplifies the importance of Floridan aquifer contribution to the lower river (Pride and Crooks, 1962). However, estimates on the amount of freshwater discharge that currently characterizes the estuary are based solely on river-discharge measurements (Montague and Odum, 1997; Bales et al., 2006). Detection and mapping of coastal groundwater discharge has become important to human and ecosystem health issues (Vanek and Lee, 1991). Increasing urban and agricultural demand for water supply and contamination problems threaten water availability and water quality to the lower basin and estuary (Katz and Raabe, 2005; Katz et al., 1999). The coastal marine/terrestrial boundary is particularly susceptible to saltwater intrusion, and aquifer drawdown may also alter surface stream flow in tidal reaches (Spechler, 2001; Barlow, 2003). Models of the Lower Suwannee River and estuary would benefit from improved understanding of water movement through subsurface limestone conduits and interaction between surface and aquifer waters (Tillis, 2000; Katz and Raabe, 2005).

Although a surficial aquifer is lacking in western Levy County and Dixie Counties, the upper boundary of the Floridan aquifer is at or nearly at land surface in the region, resulting in natural movement of groundwater to the surface (Rupert, 1988; Rupert, 1991). River discharge in the Lower Suwannee basin is enhanced by influx from aquifer base flow and from several named springs along the river (Orlando et al., 1993; Crane, 1986; Wolfe and Wolfe, 1985). Anecdotal testimony indicates the presence of numerous unnamed artesian springs and seeps located in the coastal zone and estuary, although hard evidence is scarce (Clewell et al., 1999; Rupert, 1991; Tillis, 2000). Several researchers (Montague and Odum, 1997; Raabe and Stumpf, 1996; Vernon, 1951) describe freshening of marine waters from seeps in hammocks, tidal marshes, and the nearshore area along the Big Bend coast.

The Floridan aquifer water bears a consistent temperature signature of $\sim 22$ degrees Celsius $(\mathrm{C}=$ Celsius throughout this report) year round (SRWMD, 2007). Aquifer temperature may contrast sharply with low ambient temperatures during winter cold spells and high ambient temperatures during summer months (Siegel et al., 1996). Thermal imagery has been applied to detect wildfire hot spots (Rauste et al., 1997; Beck, 2004) and for mine-drainage assessment (Sams and Veloski, 2003). Remotely sensed thermal imagery has been used to identify location and patterns of coastal karstic seeps, to map groundwater inflow and to complement point-monitoring methods (Bayari and Kurttas, 2002; Davis, 2007; Faux et al., 2001; Tcherepanov et al., 2005). Shaban et al. (2005) used Thermal Infrared (TIR) imagery to map coastal groundwater discharge and to relate discharge points to geologic structure such as fault alignment, karstic galleries, and tilted bedding planes. A previously unknown Floridian aquifer-discharge site was identified with TIR in the St. Johns River, Florida (Spechler, 1996). Benefits of airborne TIR include rapid stream-temperature surveys over a large area, detection of temperature anomalies, and mapping of thermal refugia for aquatic species, regardless of on-ground access constraints (Torgensen et al., 1995; Torgensen, et al., 2001). 
The goal of this effort was to map temperature anomalies in the Lower Suwannee, to identify potential seep locations and geographic patterns, and to identify the area affected by each feature. TIR imagery acquired with remote systems can provide high-resolution data with complete geographic coverage and thereby eliminate impacts to sensitive habitats or access issues in coastal wetlands and forested floodplains. We examined imagery for thermal anomalies in the Lower Suwannee River, the estuary, and tidal creeks between Shired Island and Cedar Key along the Gulf of Mexico.

\section{Methods}

\section{Image acquisition}

Thermal Infrared (TIR) imagery, covering $1012 \mathrm{~km}^{2}$ (250,000 acres) of the Lower Suwannee and coastal intertidal zone, was acquired by aircraft on 2-3 March 2005 (Verimap, 2005). Figure 1 shows the region covered by nighttime ( $8 \mathrm{pm}-1 \mathrm{am})$ TIR and daytime (10 am $5 \mathrm{pm}$ ) TIR, both at $1.5-\mathrm{m}$ resolution. Color Infrared imagery (CIR) was collected during daylight hours at $0.75-\mathrm{m}$ resolution. Ground temperature data collected at the time of overflight were used to calibrate the imagery. Image data values and the corresponding temperature values in degrees Celsius are shown in Table 1.

Table 1. Calibration of image values with surface temperature values.

\begin{tabular}{rr}
\hline $\begin{array}{c}\text { Temperature } \\
\text { Values (C) }\end{array}$ & $\begin{array}{c}\text { Image } \\
\text { Intensity Values }\end{array}$ \\
\hline 29 & 252 \\
28 & 244 \\
27 & 236 \\
26 & 228 \\
25 & 220 \\
24 & 212 \\
23 & 204 \\
22 & 196 \\
20 & 188 \\
19 & 180 \\
18 & 172 \\
17 & 164 \\
16 & 156 \\
15 & 148 \\
14 & 140 \\
13 & 132 \\
12 & 124 \\
11 & 116 \\
10 & 108 \\
9 & 100 \\
8 & 92 \\
7 & 84 \\
6 & 76 \\
5 & 68 \\
4 & 60 \\
\hline &
\end{tabular}




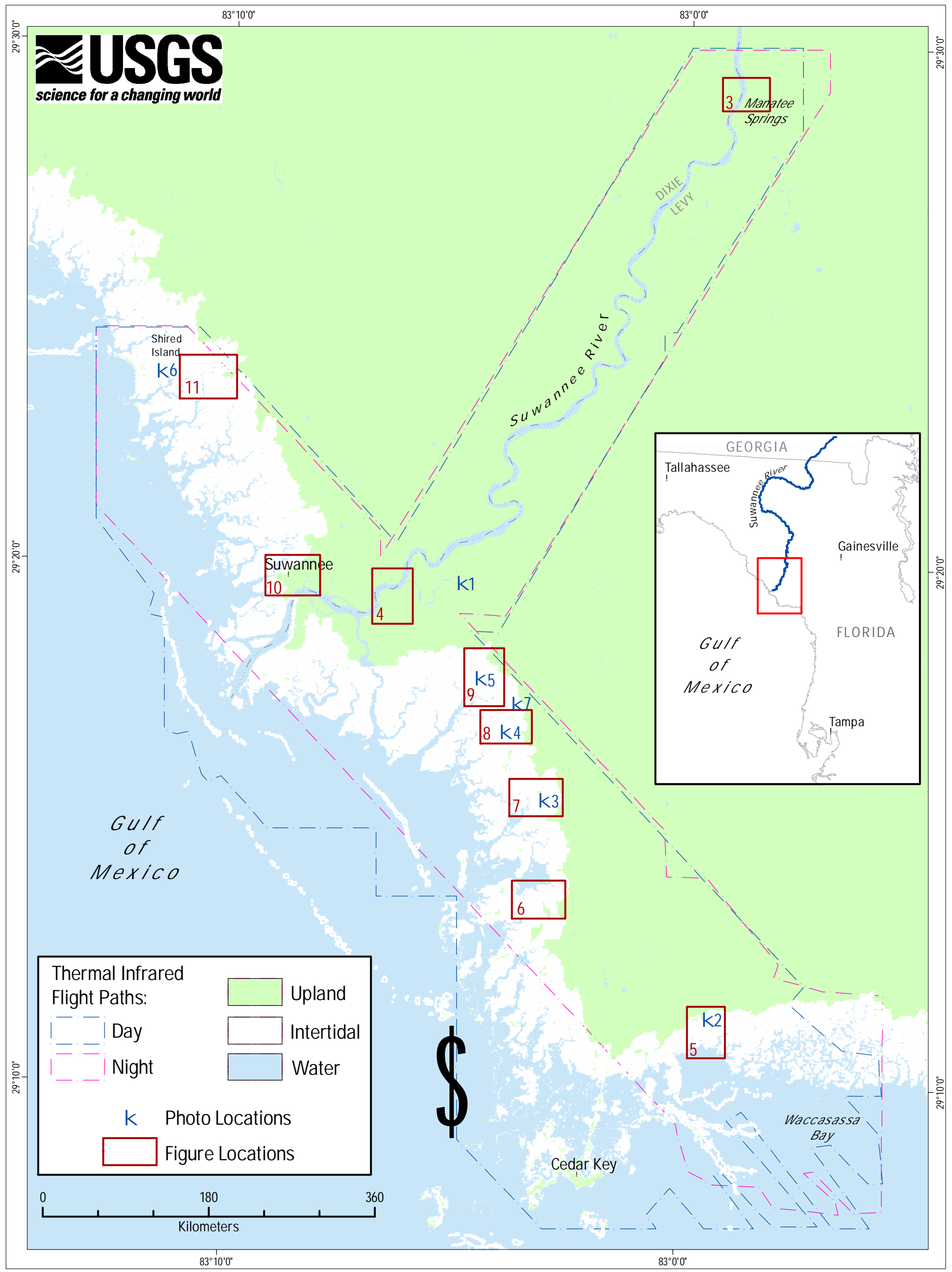

Figure 1. Lower Suwannee River location map. 
The range of temperatures provided by Verimap represents ground and water temperatures across the landscape during day and night hours. These data are generalized to non-decimaldegrees to simplify the table, although decimal degree temperature measurement is feasible. Flight

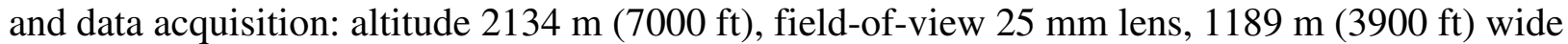
image, and $25 \%$ overlap. Imagery was geo-rectified by Verimap, the data service provider, with an approximate accuracy of $1.5 \mathrm{~m}$ and a total positional error of $+/-3.17 \mathrm{~m}$.

\section{Weather and tides}

The tides on this coast are mixed with a range of approximately $1 \mathrm{~m}$ (Stumpf and Haines, 1998). Records of actual water levels, air/water temperature, and winds at Cedar Key were obtained from NOAA historic data (NOAA, 2006). The tide cycle at Suwannee River entrance shows a lag from the Cedar Key tide gauge by 5-20 minutes. Nighttime data were acquired March 2-3 during an ebb tide with levels between -0.7 and 0.3 m MSL. Daytime data were acquired March 2 during a flood tide with water levels between -0.3 and $0.3 \mathrm{~m} \mathrm{MSL}$. Air/water temperatures at Cedar Key ranged from 8 to 12 degrees $\mathrm{C}$ during daylight hours and 7 to 10 degrees $\mathrm{C}$ during nighttime hours. Solar gain during the day can substantially increase ambient temperature of shallow water and land surfaces. Heat loss at night, moderated by large water bodies, can be expected to be greatest on land and in shallow water. Local winds were generally $\mathrm{W}$ and $\mathrm{NW}$ with maximum gusts to $6 \mathrm{~m} / \mathrm{sec}$.

\section{Feature detection}

Imagery was obtained from Verimap at full-resolution $(1.5 \times 1.5 \mathrm{~m}$ pixels $)$ in several blocks because of the large file size. The imagery was processed with image processing software to identify and highlight temperature anomalies. Temperature of the Floridan aquifer is constant between 21 and 22 C (SRWMD, 2007) and equates to image values of 190 to 202. However, temperature of aquifer outflow is quickly moderated by mixing with surface waters. The goal of image processing was to identify the location and trace of aquifer seeps by mapping anomalies from TIR. A water-only mask was created from the CIR imagery to eliminate temperature anomalies on land. Initial evaluation showed that temperature anomalies could be identified at $3 \mathrm{~m}$ resolution. The individual blocks of imagery were mosaicked into single layers for night and day at $3 \mathrm{~m}$ resolution to reduce processing time and to facilitate consistent analysis.

A consistently high background temperature in the Suwannee River emanated from Manatee Springs (Fig. 1). Manatee Springs is a first-order spring with an average discharge of 142 cfs (SRWMD, 2007). Higher ambient river temperature had the potential to mask smaller temperature anomalies in the riverbed from Manatee Springs to the estuary.

Since shallow waters are prone to temperature increase during daylight hours, analysis focused on evening-temperature anomalies for confidence and accurate identification of aquifer seepage. Temperature range in night TIR was 22 degrees $C$ (4-26 degrees $C$ ). Natural breaks in the night imagery occurred at 8-9 degrees $\mathrm{C}$ and at 13-14 degrees $\mathrm{C}$. The lower break represents water in the tidal creeks, and the upper break represents water in the river. A threshold was established for each water body, and only values exceeding the background temperature were mapped. The background temperature for the tidal creeks was set at 10 degrees $\mathrm{C}$ (98\% of tidal water pixels). The background temperature for the river and its plume was set at 14 degrees $\mathrm{C}$. Hot spots mapped in tidal creeks and river exceeded ambient water temperature by four degrees $\mathrm{C}$ or more. Features mapped as a plume, or warm-water trace, exceeded ambient water temperature by one degree $\mathrm{C}$ or more. 
TIR acquired during the day was more complex with solar energy warming both land and water features. Again, only temperature anomalies in the water were evaluated. Background temperatures for daytime TIR were set to 14 degrees $\mathrm{C}$ in the tidal creeks and 18 degrees $\mathrm{C}$ in the river. Mapped hot spots exceeded ambient water temperature by four degrees $\mathrm{C}$, and plumes exceeded ambient water temperature by one degree $C$ or more. Seep features at the mouth of the river and elsewhere in the estuary could not be identified from night TIR, which was not acquired along the coast. Instead, the single daytime thermal was used to identify potential sites. Daytime warming of shallow water may interfere with accurate feature identification and warrants caution in use and applications of daytime TIR imagery alone. In an effort to increase confidence of warm water features, an additional plume was derived from warm-water pixels coincident to both day and night imagery.

All identified features were within the tidal creeks or the tidal reach of the river, which introduced another conundrum. Outgoing tide during the evening hours produced a plume heading downstream to the Gulf of Mexico. Higher water levels and an incoming tide during the daylight hours produced a plume in the opposite direction. A complete overlap of warm-water features cannot be expected given the direction of flow. The digital release includes identification of features identified in both night and day imagery and those that could be identified only in a single image.

Image artifacts at flight-line boundaries displayed false-positive high temperature values along flight-line edges. Rule-based editing was used to remove flight-line artifacts from derived warm-water features. Features in flight-line overlap zones, showing a strong temperature anomaly and accompanied by a plume or by a geographically coincident feature during day and night acquisition, were retained. Features occurring at flight edge, or having no temperature anomaly 'double', were eliminated. There may be some remaining artifacts along image edge and minor mis-registration issues. Potential or known features outside the image bounds must be considered 'unidentified' rather than non-existent. body:

Steps taken to extract features exhibiting warmer temperatures than the surrounding water

1. Develop water-only layer for extraction of water features.

2. Establish background temperatures for river and tidal creeks in night and daytime TIR imagery.

3. Extract features exceeding the background: four degrees $\mathrm{C}$ or more for hot spots and one degree $\mathrm{C}$ or more for plumes.

4. Create intersection of night and day warm-water areas to highlight and confirm location of plumes.

5. Remove/eliminate flight-line artifacts.

6. Confirm hot spots by raising temperature threshold, check against plumes, direction of tidal flow, and compare features from day/night imagery.

7. Conduct field reconnaissance to verify features. 


\section{Results}

Figure 1 shows the area of data acquisition. Night and day acquisition areas were slightly different and are delineated by dashed outlines. Features derived from the imagery are shown as hot spots, plumes, and coincident night and day 'warm' zones in Figure 2, an interactive map. Select temperature anomalies are displayed in detailed maps and photos in the following pages.

Figure 2. Interactive map of temperature anomalies on Lower Suwannee River and tidal creeks.

\section{Lower Suwannee River}

Manatee Springs and its plume are shown in Figure 3. The plume was clearly visible in both night and daytime TIR and the trace of warm water continued downriver. Few features were mapped for about $25 \mathrm{~km}$ downstream of this first-order spring.

During the ebb tide at night, colder Gulf waters exerted an influence beyond Gopher River, and temperature anomalies in this area could be differentiated (Fig. 4). Field investigations in the Gopher River area turned up vegetation anomalies (Photo 1) and the presence of manatees, but the temperature signal was difficult to pin down to a point source. Fractures or linear fissures in the limestone or deeper water may be responsible for a more diffuse temperature signal from aquifer seeps in this area. Differences in plume direction and extent were related to tidal cycle. A good example of the influence of tide direction may be seen in Figure 4 at Dead Boy Creek. A hot spot is located between two plumes: the plume to the east was primarily daytime tidal flood, and the plume to the west was captured during the ebb tide at night.

Photo 1. Herbaceous wetland vegetation was associated with the seep on Gopher River.

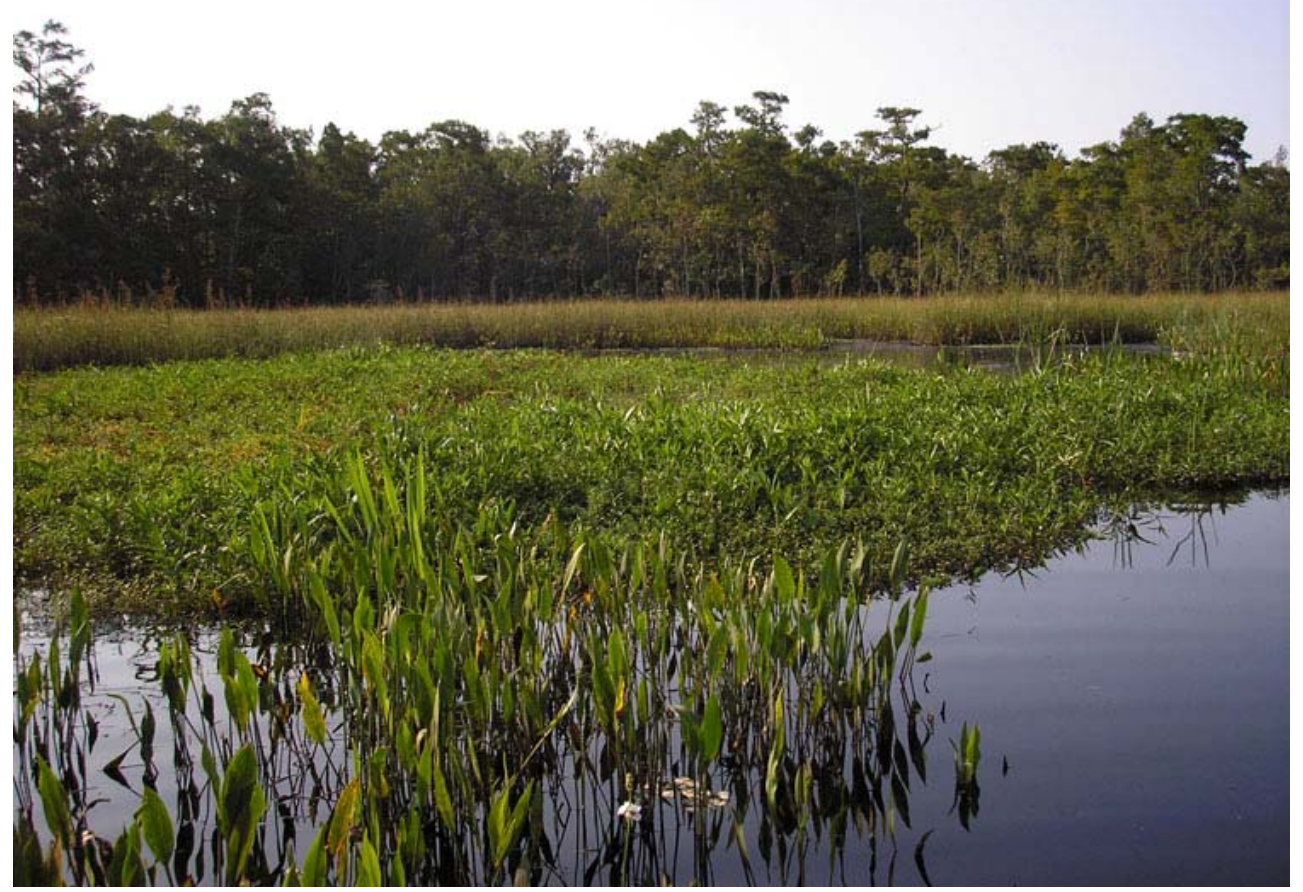




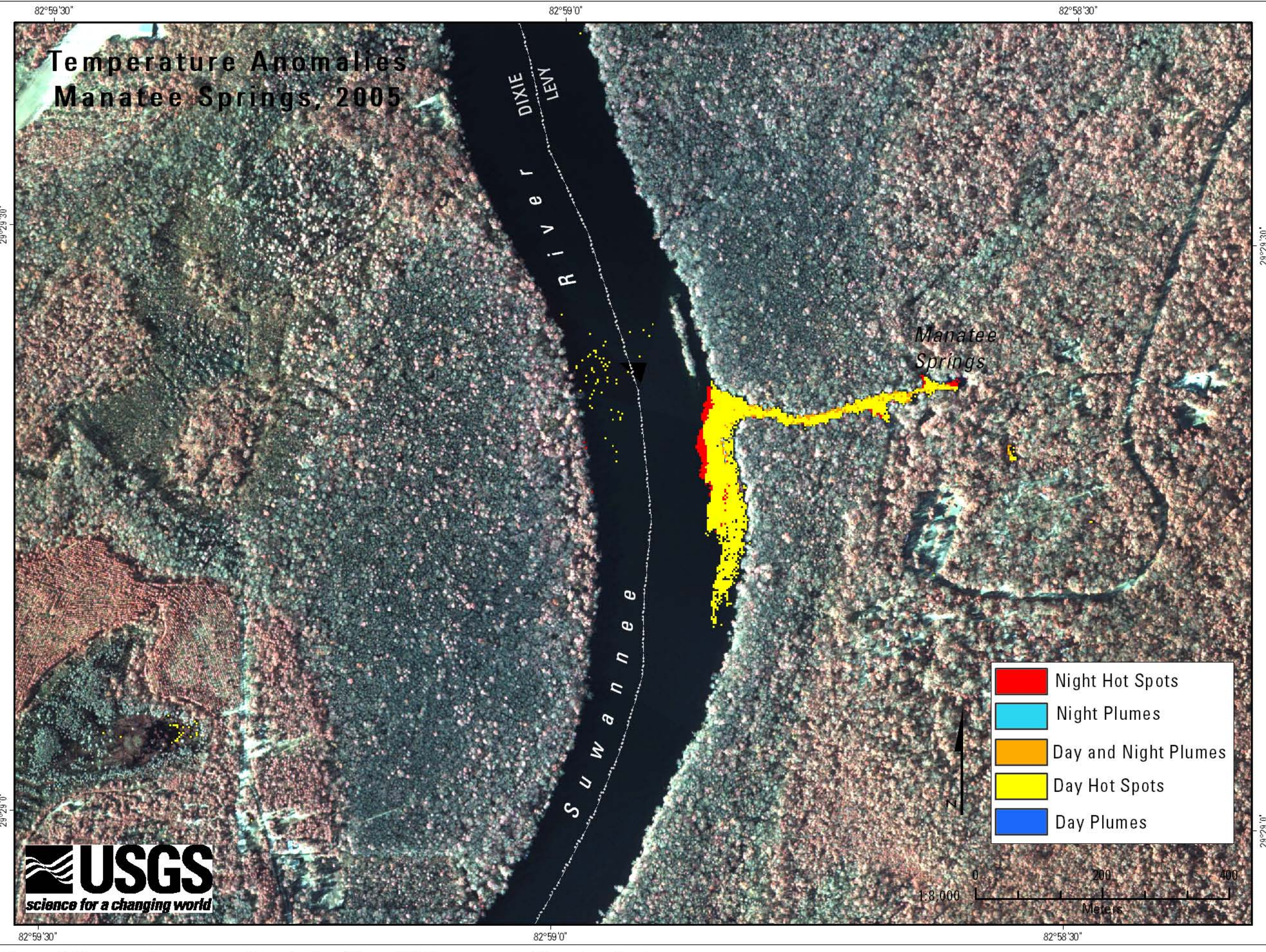

Figure 3. Temperature anomalies derived from TIR imagery at Manatee Springs. 


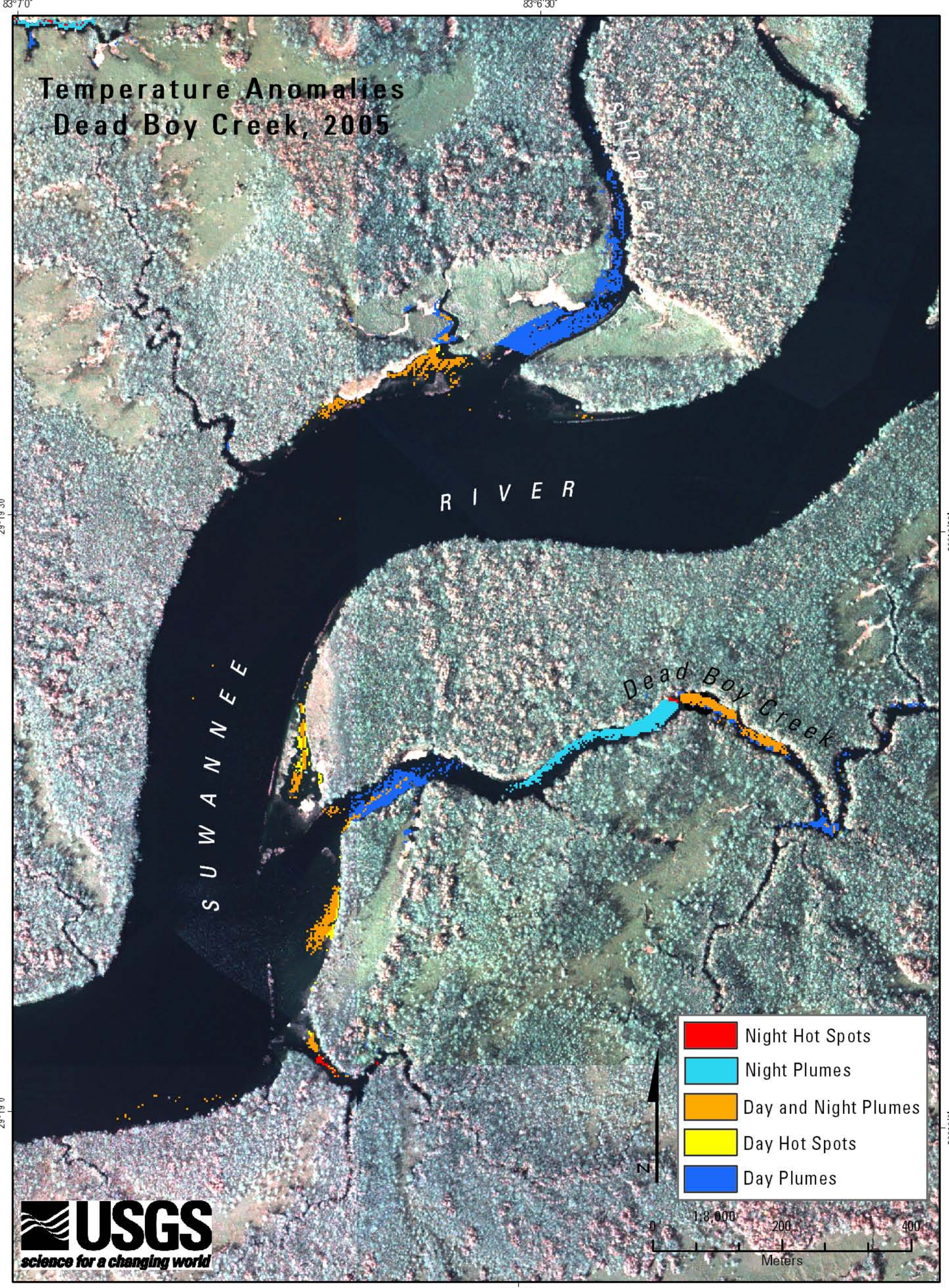

Figure 4. Temperature anomalies derived from TIR imagery at Dead Boy Creek. 


\section{Spring Creek}

A known feature was included in the flight pattern and is shown in Figure 5. Spring Creek (Photo 2) exhibits a warm plume originating at a small spring in a wooded hammock and influencing water temperature the length of the stream to Waccasassa Bay, about $1.2 \mathrm{~km}$ to the south. This spring has several visible boils at all times and the water is fresh. Several other plumes and hot spots along the north of Waccasassa Bay and east of Cedar Key were also mapped.

Photo 2. Spring Creek runs through a small hammock before entering the tidal creek.

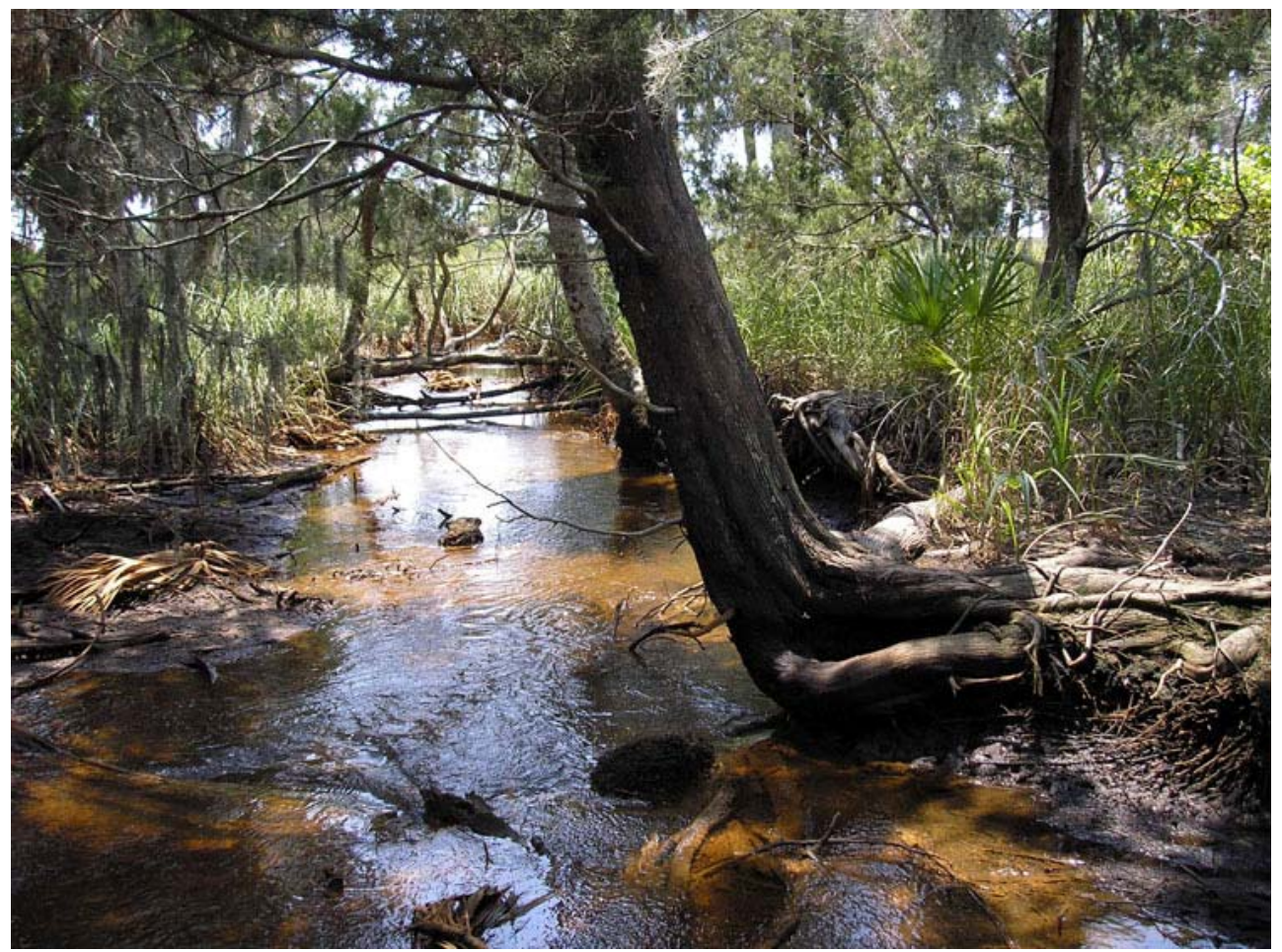

\section{Tadpole-shaped features}

Several tadpole-shaped features were mapped in the intertidal zone. Examples are shown in Figures 6, 7, and 8. These features, confirmed with summer field reconnaissance, typically consisted of a pond with a small boil (Photo 3), connected to the tidal creek by a narrow outlet, creating a tadpole-shape outline (Photo 4). The boils were small, ranging from 30 to $60 \mathrm{~cm}$ across, and shallow, ranging from 0.5 to $2 \mathrm{~m}$ deep. Discharge is unknown, but given the small size of the boils, an estimate of $1 \mathrm{cfs}$ is expected. Plumes from each feature extended a considerable distance downstream, 0.1-1.5 km, and in some cases mingled with plumes from nearby seeps. Alligator sightings were common at these locations. Temperature anomalies at the boils were confirmed by a temperature difference of 4-10 degrees $\mathrm{C}$ lower than the creek itself, during summer high temperature levels. 


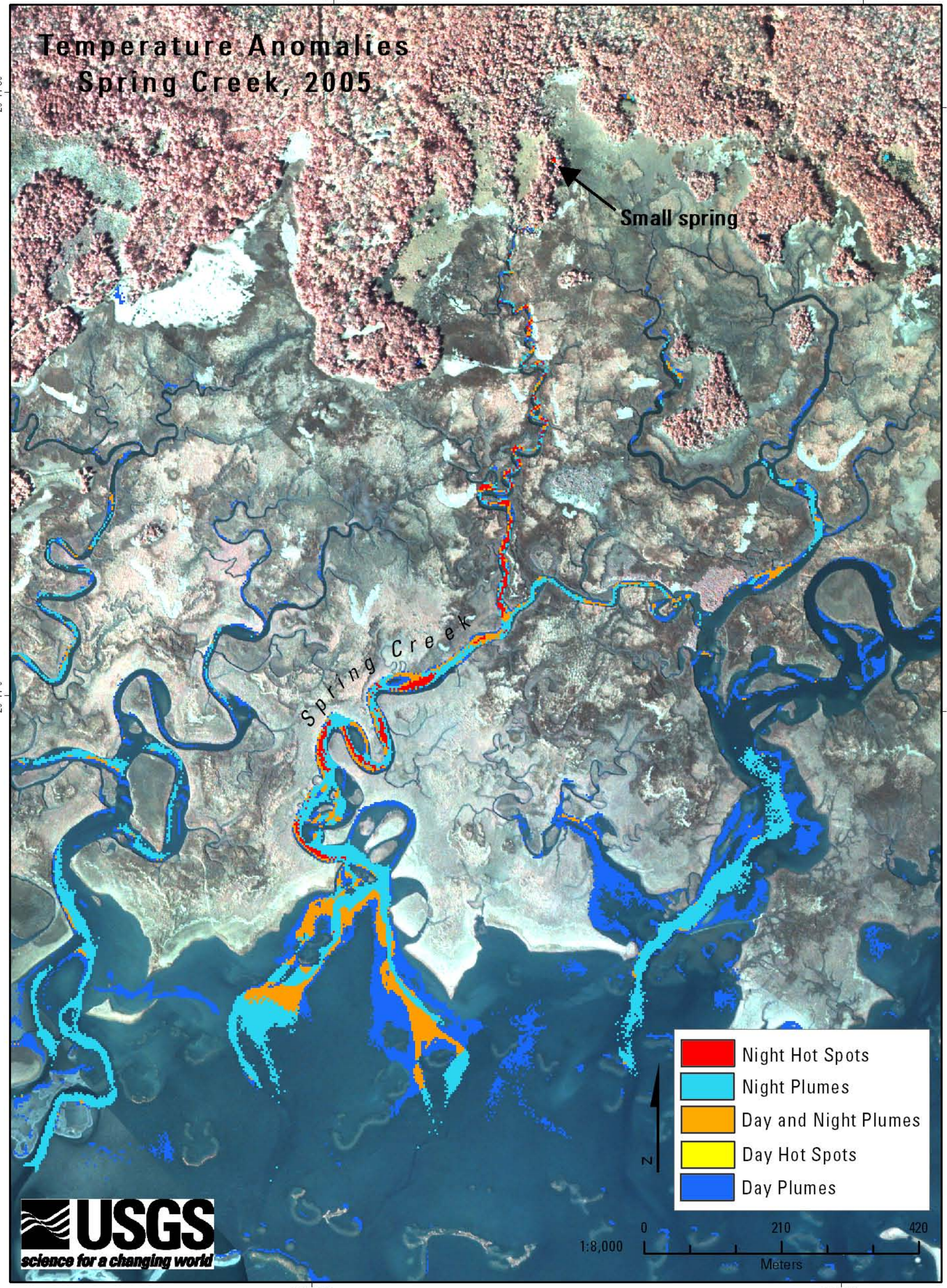

$82^{\circ} 59^{\prime} 30^{\prime \prime}$

$82^{\circ} 59^{\prime} 0^{\prime \prime}$

Figure 5. Temperature anomalies derived from TIR imagery at Spring Creek. 


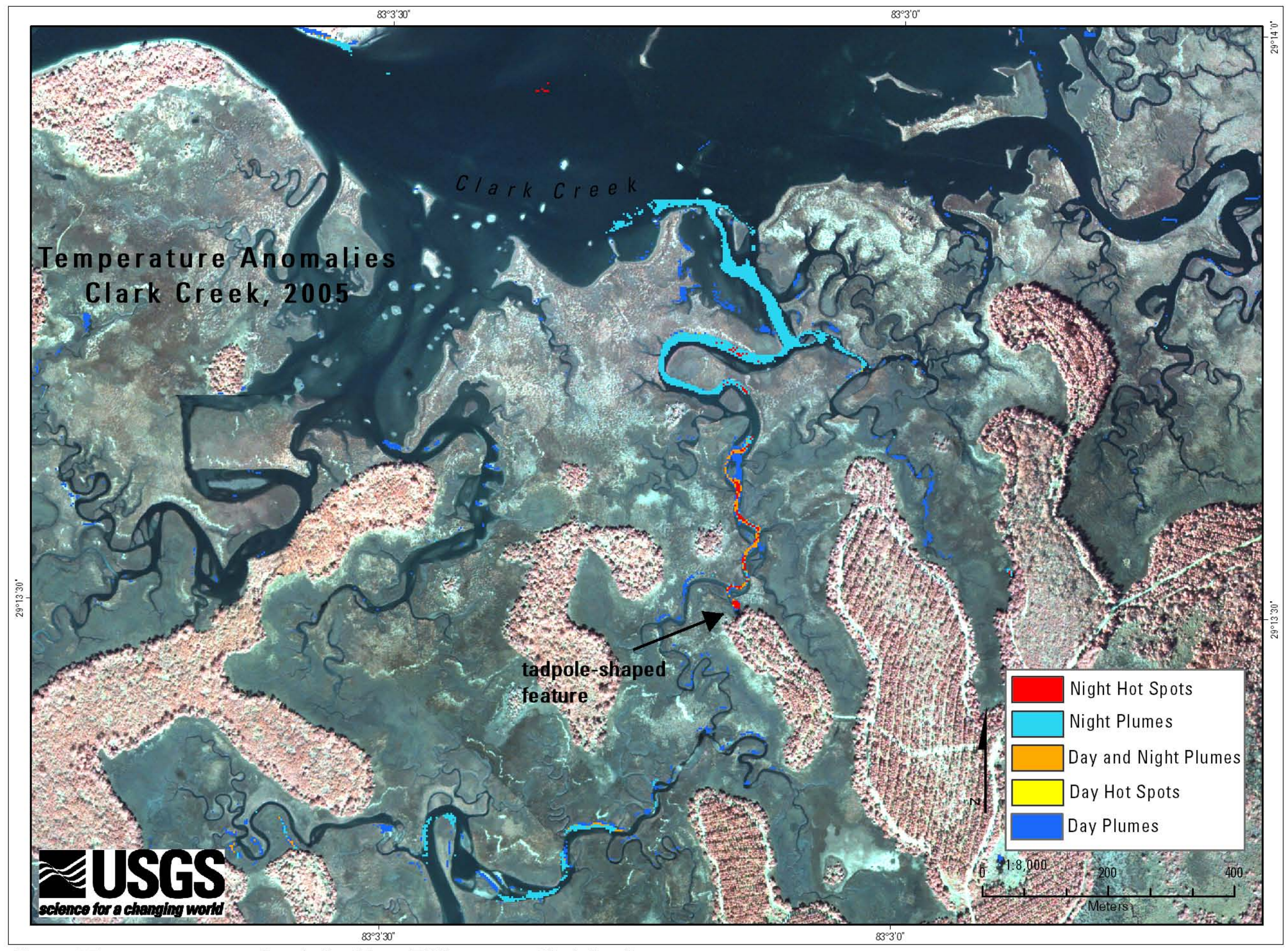

Figure 6. Temperature anomalies derived from TIR imagery at Clark Creek. 


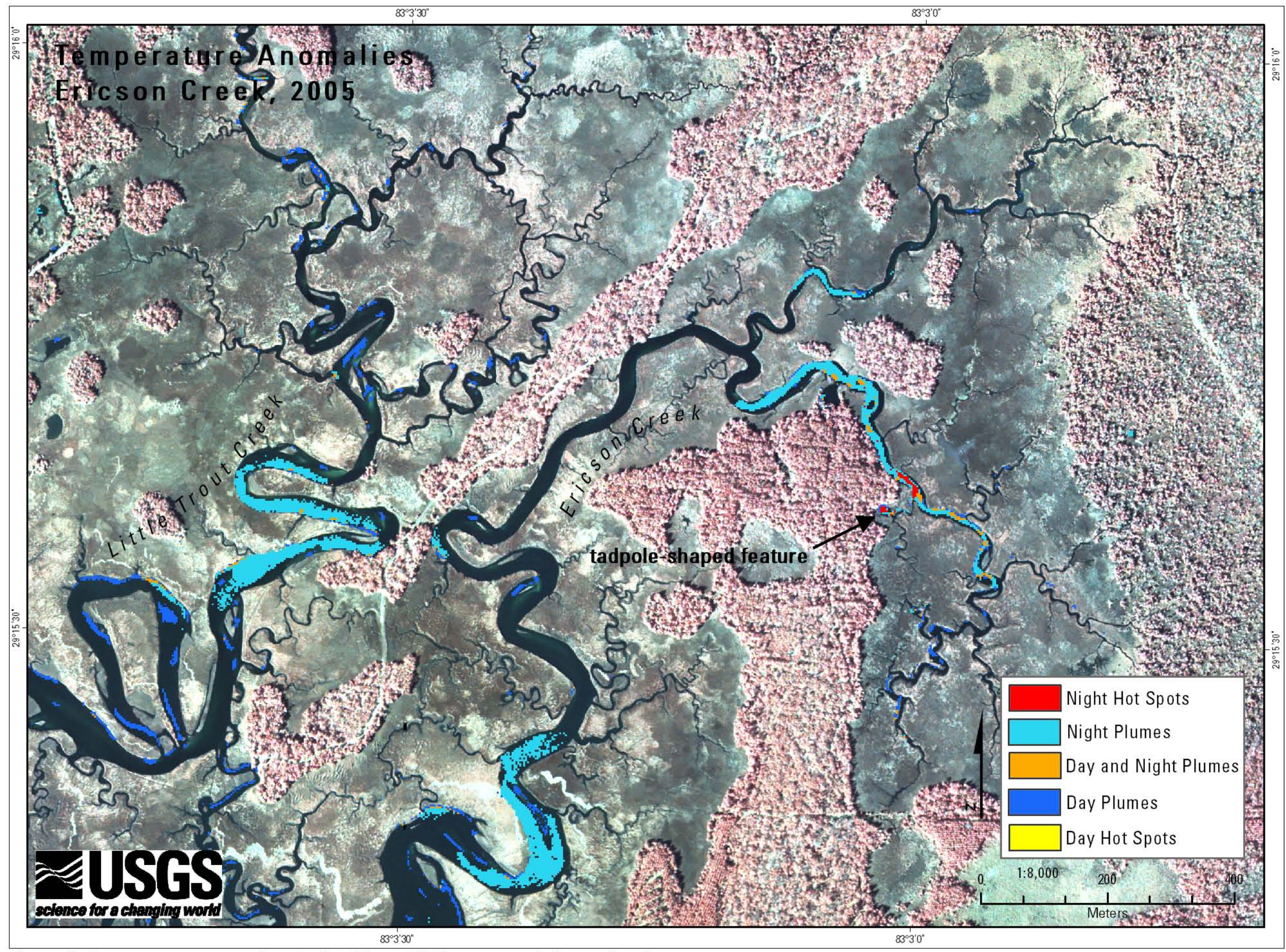

Figure 7. Temperature anomalies derived from TIR imagery at Ericson Creek. 


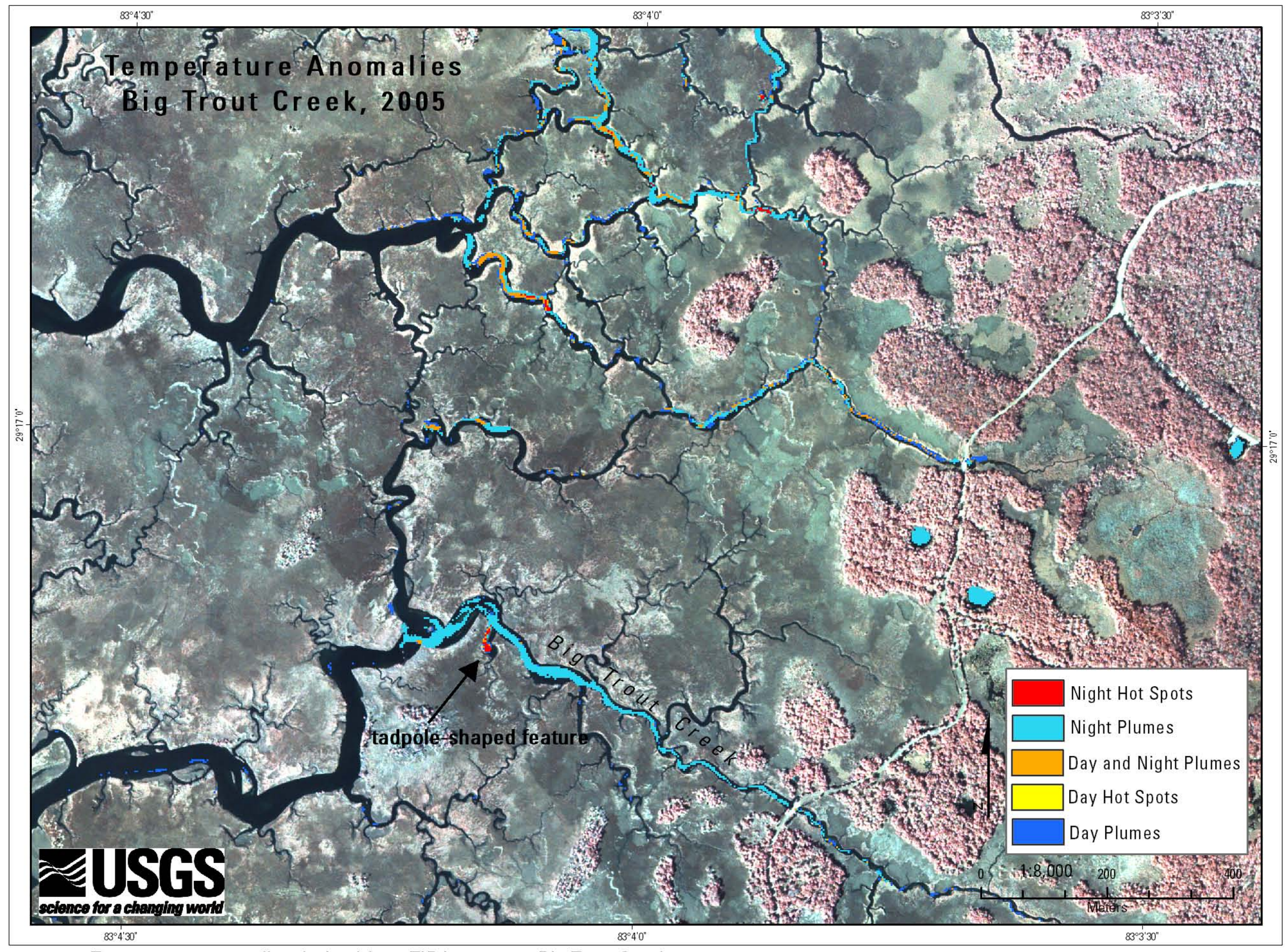

Figure 8. Temperature anomalies derived from TIR imagery at Big Trout Creek. 
Photo 3. A small boil was identified on Ericson Creek.

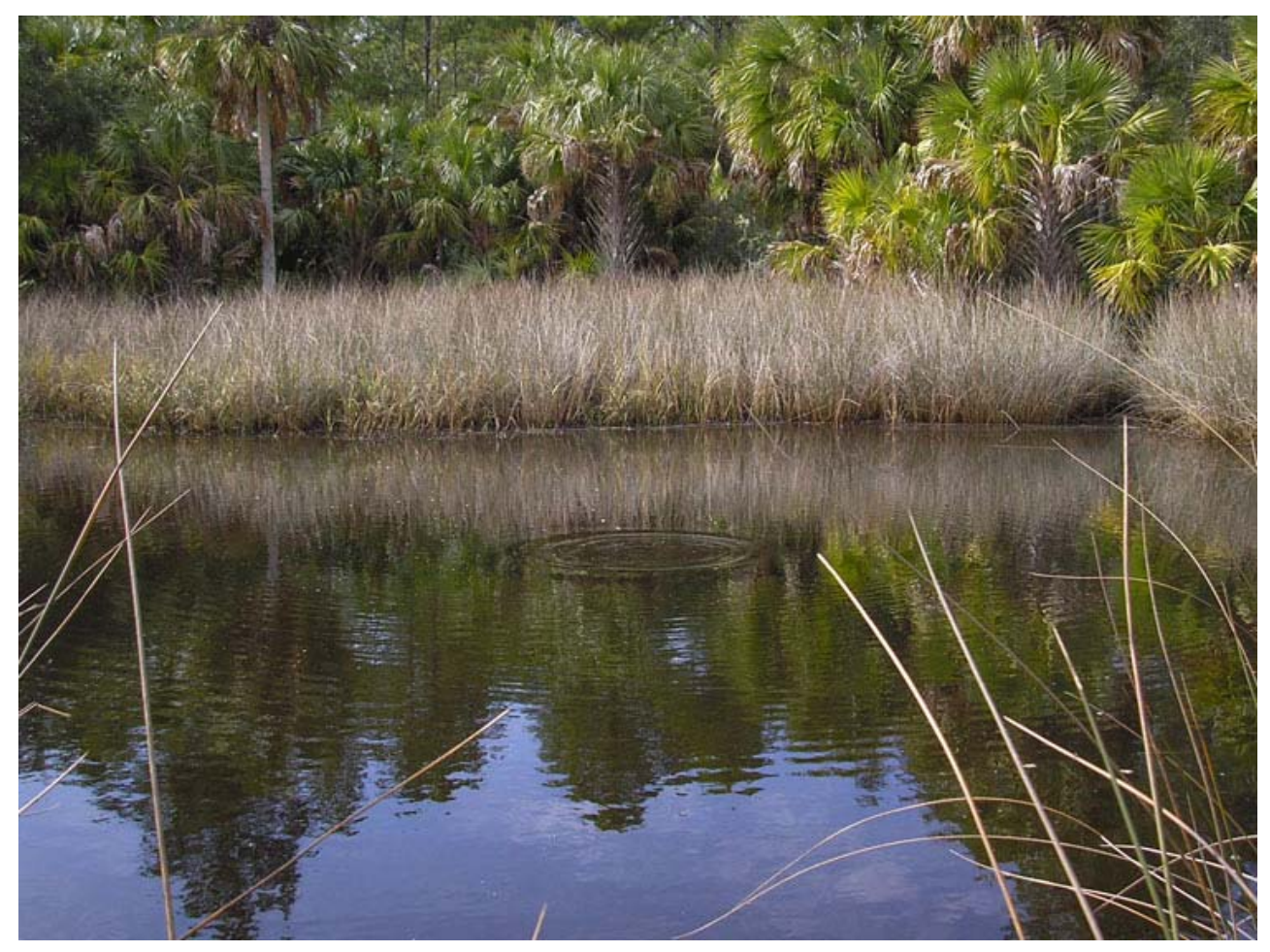

Photo 4. A small boil feeds a tadpole-shaped feature on Big Trout Creek.

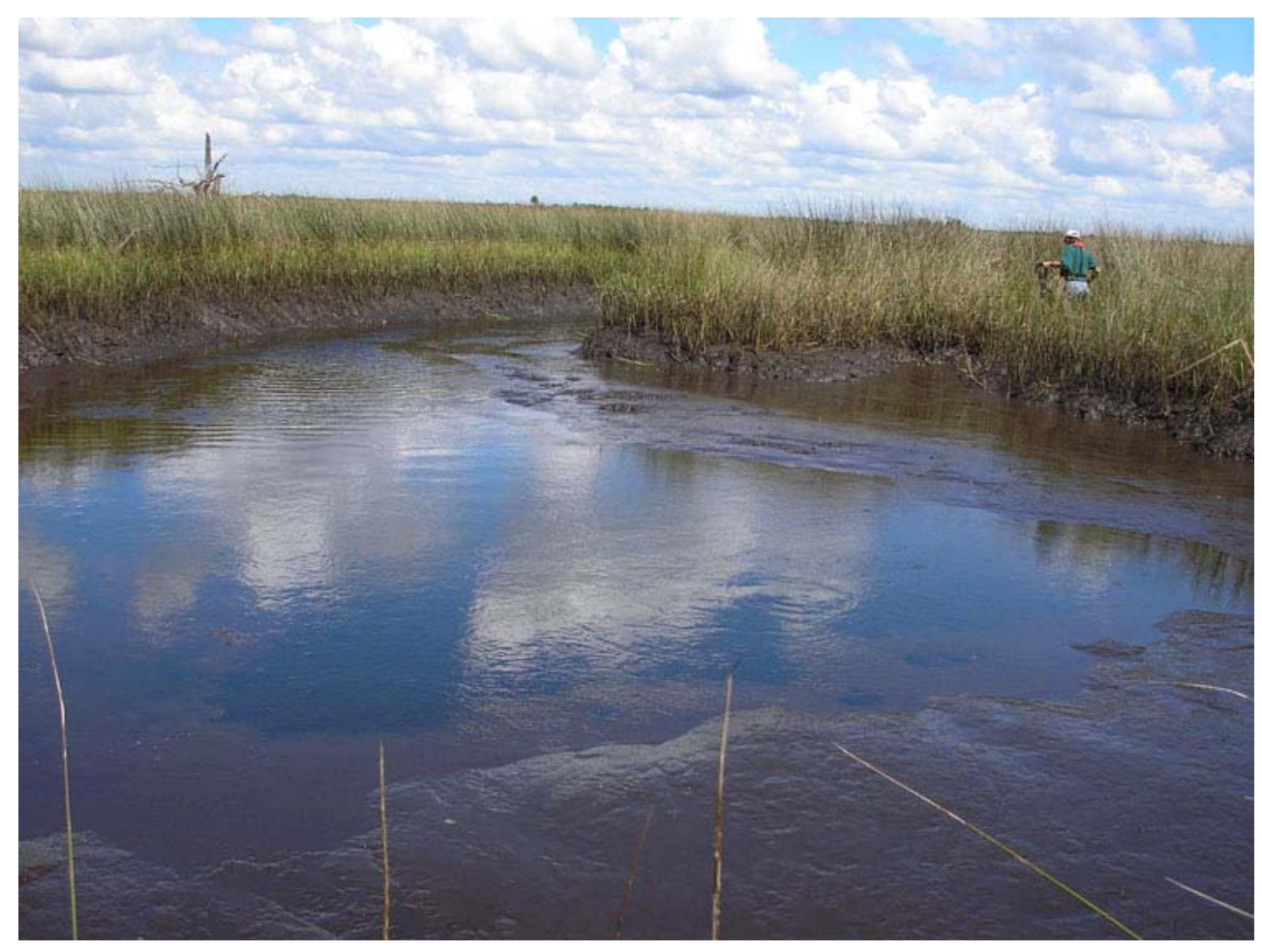


Other features were small, or flow was so diffuse that minor mis-registration between day and night images made them indiscernible in a combination of day and night imagery, but were identifiable with one or the other singly and often as a single pixel. These features may be small in size or flow but represent a viable feature on the ground. An example of such a feature is illustrated in Photo 5. This site was field-identified as a small boil in a tadpole-shape feature, surrounded by sawgrass, off a northeast Barnett Creek tributary, and nicknamed Stillwater Pond. The boil is inconsistent, becoming visible to the eye only when groundwater levels are rising.

\section{Photo 5. Sawgrass surrounds Stillwater Pond.}

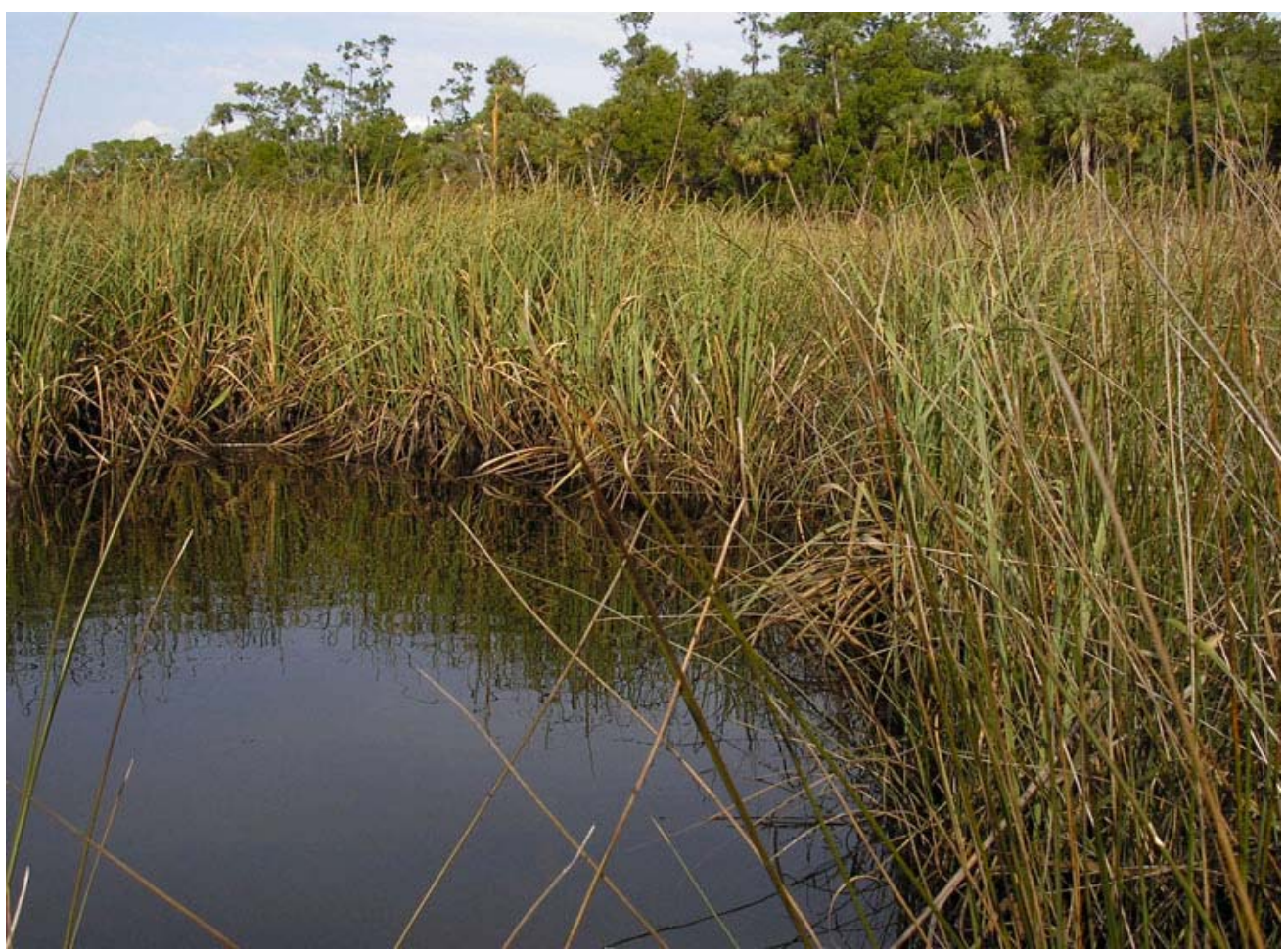

\section{Limestone fractures}

Other temperature anomalies occupy a length of the creek bed itself. Figure 9 shows the eastern branches of McCormick Creek, where the features are numerous and a warm-water trace extends the length of the tributary. Field reconnaissance in this area was halted by low water and widespread exposed limestone in the creek bed (Photo 6). Summer water temperatures were consistently lower than in nearby creeks, and both mature and juvenile manatees were sighted nearby. The exposed limestone and plume configuration indicates an underlying dissolution feature or fracture, connecting many diffuse seeps within a single tidal creek. 


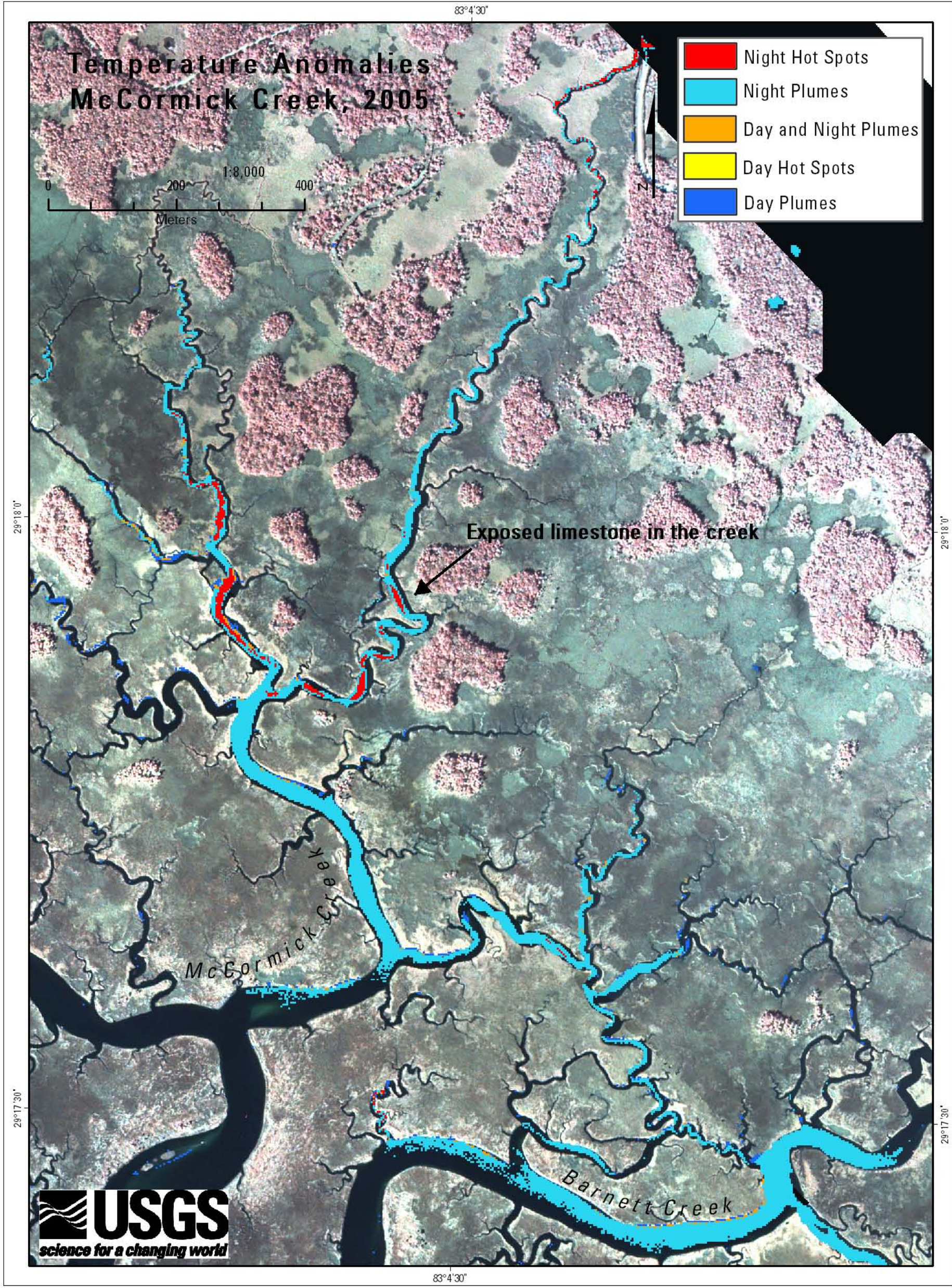

Figure 9. Temperature anomalies derived from TIR imagery at McCormick Creek. 
Photo 6. Exposed limestone lines this section of McCormick Creek.

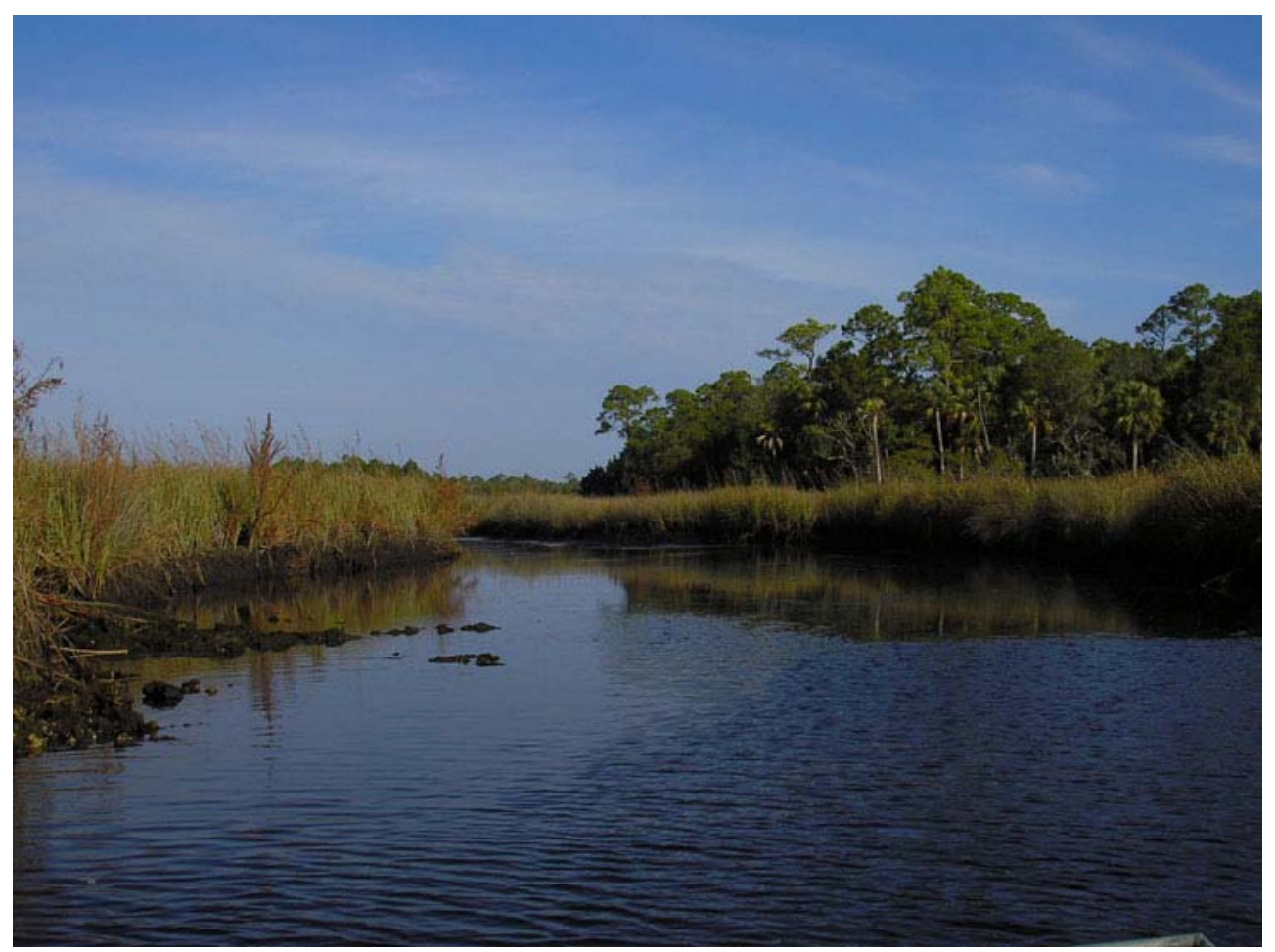

\section{Northern tidal creeks}

Fewer distinct temperature anomalies were identified north of the Suwannee River. Tidal creeks to the north of the river showed warm-water plumes, but hot spots were less frequent than south of the river. Figure 10 shows warm-water anomalies at the town of Suwannee in the canals leading between the marina and residences. It is possible these anomalies represent sewage effluent. On the other hand, where the aquifer-bearing limestone is near surface, construction of canals may have cut into dissolution features within the underlying rock, releasing aquifer flow to the canals.

Figure 11 shows distinct temperature anomalies on Sanders Creek and Johnson Creek (Photo 7). The warm-water feature at Sanders Creek has a distinct signature in night TIR and includes a warm-water plume extending $1.5 \mathrm{~km}$ downstream. Virtually no temperature anomalies were mapped within the estuary. Since the night TIR imagery did not encompass the estuary, the absence of derived features at the river mouth may not be definitive.

\section{Discussion}

Detection of temperature anomalies was produced with image post-processing, using a combination of night and day TIR, CIR, the setting of background temperatures, and rule-based procedures. The derived features shed light on the location and geographic distribution of seeps in the coastal zone from Manatee Springs on the Suwannee River to tidal creeks along the Gulf of Mexico from Shired Island to Cedar Key. Prominent features were discernable in both day and night TIR imagery. Other features were observed only in one image or the other. Seeps, boils, and spring runs were confirmed with field reconnaissance. 


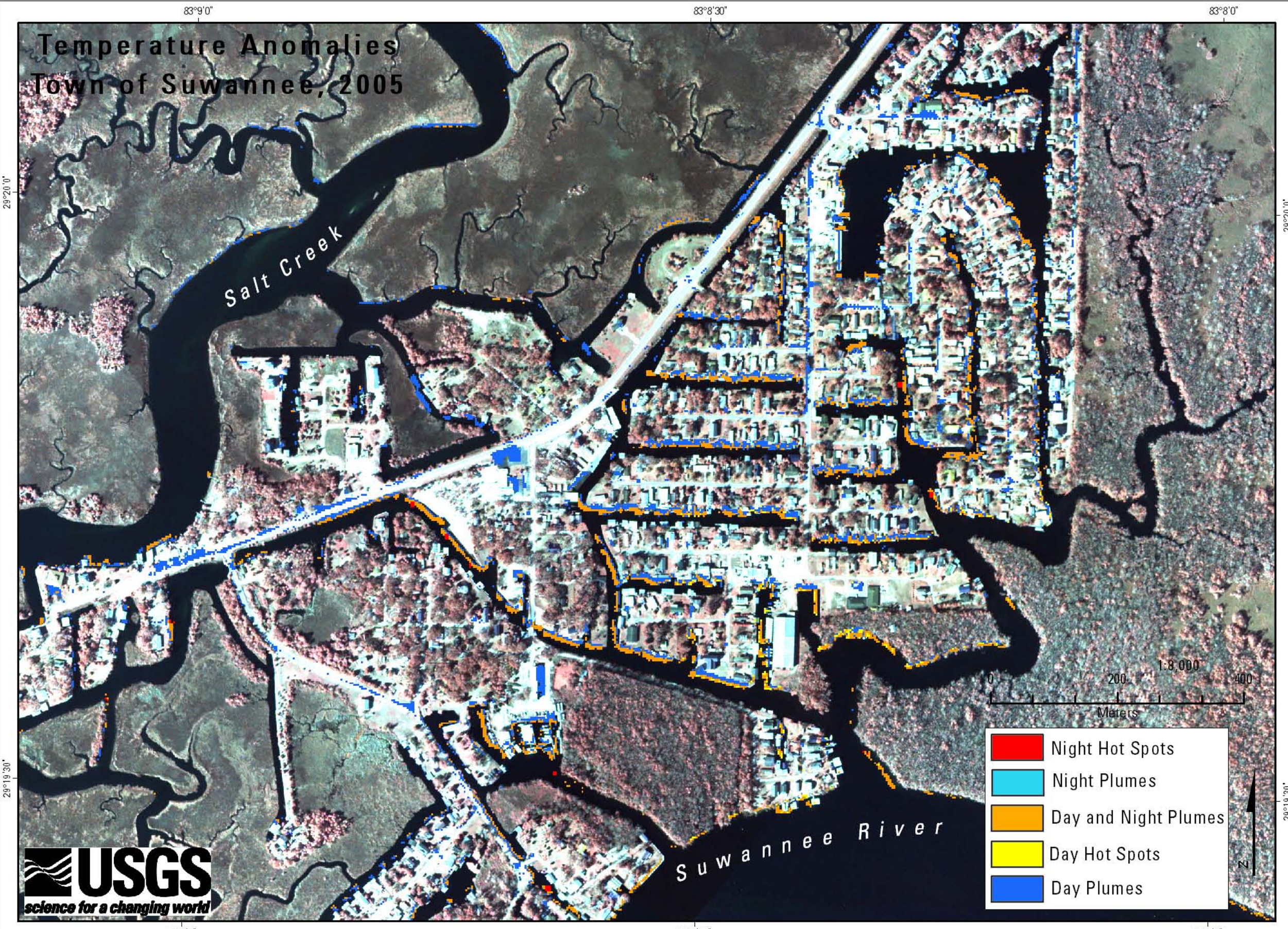

Figure 10. Temperature anomalies derived from TIR imagery at Town of Suwannee. 


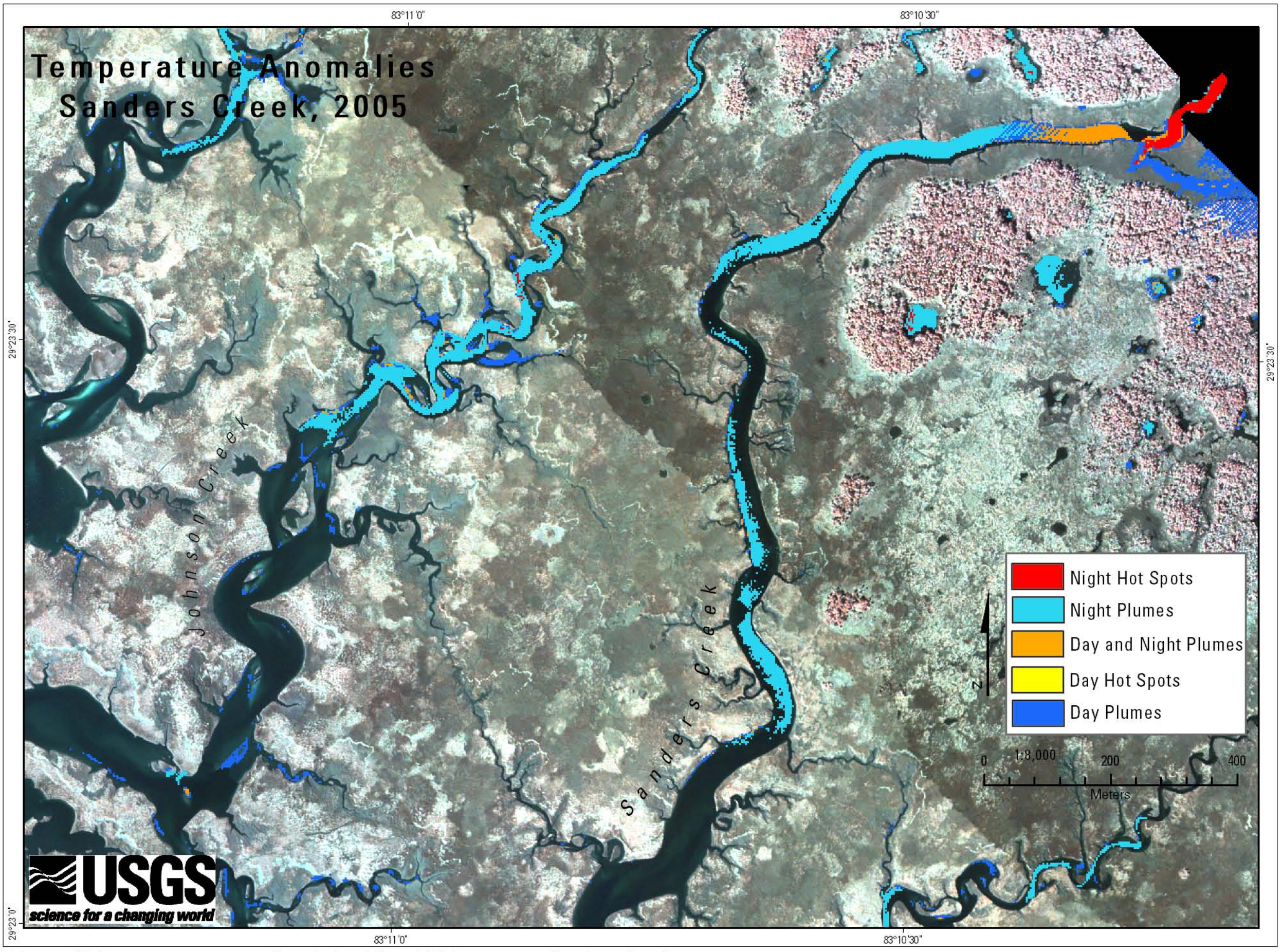

Figure 11. Temperature anomalies derived from TIR imagery at Sanders Creek. 
Photo 7. Oyster bars were associated with temperature anomalies on Johnson Creek.

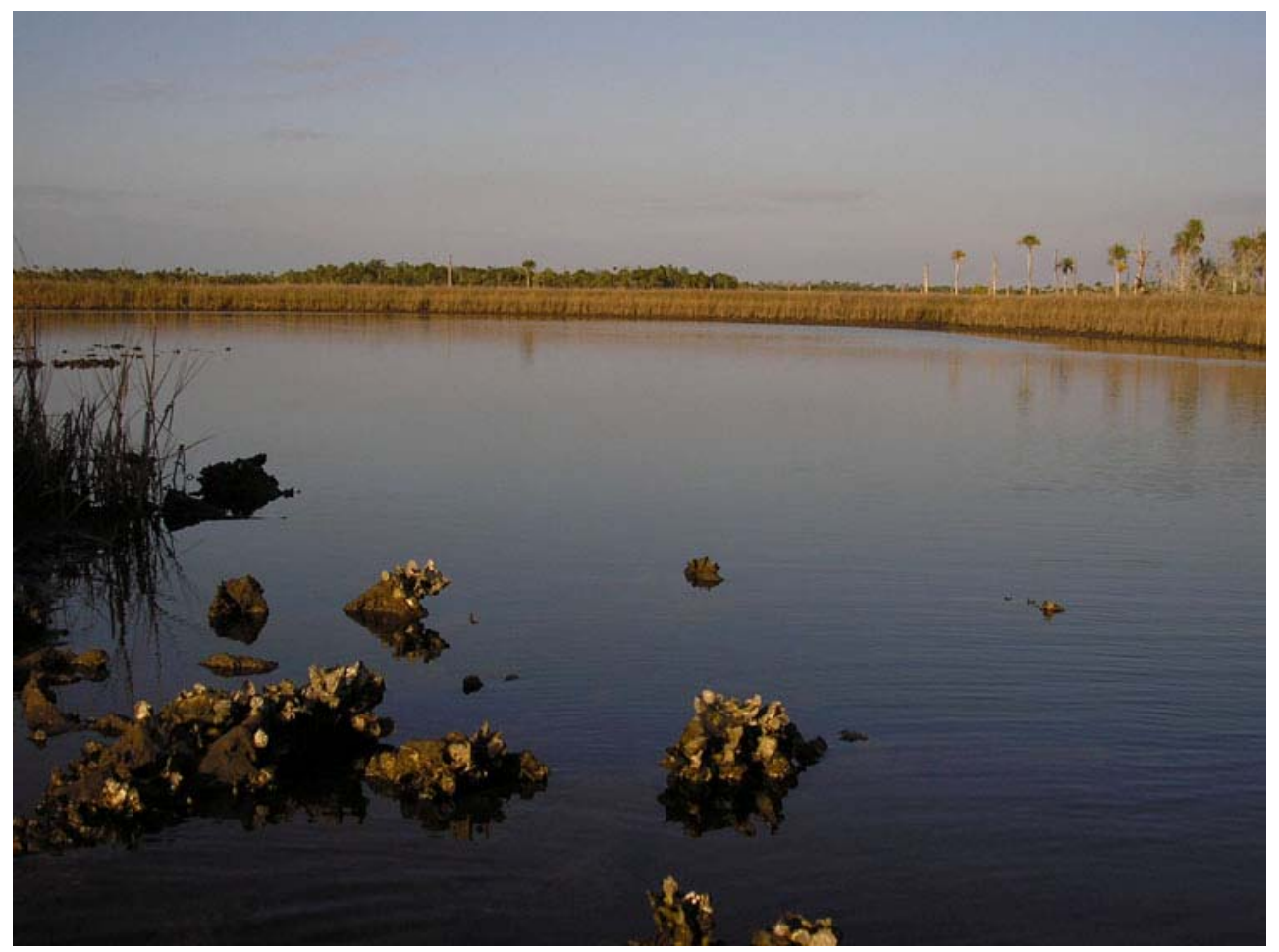

Derived features represent a conservative estimate of potential seeps due to the "masking" of features along the river, the loss of features in flight-line artifacts, and the absence of night TIR in the estuary itself. Many small temperature anomalies were successfully detected along the tidal creeks. Anomalies along the lower river may have been obscured by discharge volume or by sheer number of seeps. The discharge at Manatee Springs represents 1-2 \% of river discharge at the Gulf of Mexico as reported by Orlando et al. (1993). It is likely the presence of many seeps and diffuse or deep-water sources contributed to the temperature anomaly along this $20-25 \mathrm{~km}$ stretch of river. Seismic profiles or bathymetric maps of this stretch of the river could shed light on the underlying limestone and clarify seep locations.

The Floridan aquifer plays an important role in water quality and supply to the estuary. The maps show multiple features and clearly delineated plumes throughout the intertidal zone from a single date along a limited section of coastline. This is the tangible evidence needed to confirm frequent anecdotes describing seepage from the Floridan aquifer along the coast. The area east of Spring Creek in Waccasassa Bay appears to be riddled with interconnected dissolution features. This appears to confirm White's (1958) description of a weakened limestone with large numbers of sinkholes and mass wasting. Multiple aquifer seeps indicate that the process of dissolution is reasonably active today. The imagery effectively illustrates the somewhat tenuous boundary between the Floridan aquifer and surface waters in the Lower Suwannee River and Gulf tidal creeks. A prevalence of temperature anomalies emphasizes the vulnerability of this coastal region to aquifer drawdown, contamination, and saltwater intrusion. 


\section{Products}

DVD release of USGS Open-File Report 2007-1311 includes: (1) open-file report, (2) data layers provided as individual GeoTIFF raster files for each derived feature (night and day hot spots and plumes), (3) CIR imagery, (4) metadata, and (5) interactive Figure 2 provided in a tif format for viewing option.

\section{Acknowledgements}

Imagery was acquired in cooperation with Sarah Kruse (University of South Florida). Lower Suwannee NWR personnel and Jeff DiMaggio (Park Manager, Waccasassa Bay Preserve State Park) provided field and ground support. David Stonehouse (VeriMap) provided the initial 'proof-of-concept' flight and expert advice. 


\section{References Cited}

Bales, J.D., Tomlinson, S.A., and Tillis, G., 2006, Flow and salt transport in the Suwannee River Estuary, Florida, 1999-2000, Analysis of data and three-dimensional simulations: U.S. Geological Survey Professional Paper 1656-B, 66 p.

Barlow, P.M., 2003, Ground water in freshwater-saltwater environments of the Atlantic Coast: U.S. Geological Survey Circular 1262, 113 p.

Bayari, C.S., and Kurttas, T., 2002, Coastal and submarine karstic discharges in the Gökova Bay, SW Turkey: Quarterly Journal of Engineering Geology and Hydrology, v. 35, no. 4, p. 381-390.

Beck, J., 2004, Capabilities of airborne infrared remote sensing systems to detect hotspots: Adventage, v. 5, no. 11, 15 p.

Brooks, R.A., and Sulak, K., 2004, Quantitative assessment of benthic food resources for juvenile Gulf sturgeon, Acipenser oxyrinchus desotoi in the Suwannee River Estuary, Florida, USA: U.S. Geological Survey Investigation Report CEC 2004-02, 11 p.

Carr, S.H., Tatman, F., and Chapman, F.A., 1996, Observation on the natural history of the Gulf of Mexico sturgeon (Acipenser oxyrinchus de sotoi Vladykov 1955) in the Suwannee River, southeastern United States: Ecology of Freshwater Fish, v. 5, no. 4, 169 p.

Chapman, F.A., and Carr, A.H., 1995, Implications of early stages in the natural history of the Gulf of Mexico sturgeon, Acipenser oxyrinchus de sotoi: Environmental Biology of Fishes, v. 43, no. 4, p. 407-413.

Clewell, A.F., 2000, Inventory of tidal marsh vegetation along the Suwannee River during drought in June 2000: Live Oak, FL, Suwannee River Water Management District, 15 p.

Clewell, A.F., Beaman, R.S., Coultas, C.L., and Lasley, M.E., 1999, Suwannee River tidal marsh vegetation and its response to external variables and endogenous community processes: Live Oak, FL, Suwannee River Water Management District, 119 p.

Crane, J.J., 1986, An investigation of the geology, hydrogeology, and hydrochemistry of the Lower Suwannee River basin: Florida Geological Survey Investigation Report 96, 110 p.

Darst, M.R., Light, H.M., and Lewis, L.J., 2002, Ground-cover vegetation in wetland forests of the Lower Suwannee River Floodplain, Florida, and potential impacts of flow reductions: U.S. Geological Survey Water-Resources Investigations Report 02-4027, 46 p.

Davis, J.B., 2007, Aerial thermography surveys to detect groundwater discharge in the St. Johns River Water Management District, Northeast Florida: American Society of Photogrammetry and Remote Sensing, Annual Conference, Tampa, Florida, USA, 9 p.

Edwards, R.E. and Raabe, E.A., 2004, Ecological Characteristics and Forcing Functions of the Suwannee River Estuary, in Katz and Raabe, (eds.), Suwannee River Basin and Estuary Integrated Science Proceedings, September 22-24, 2004, Cedar Key, FL: U.S. Geological Survey Open-File Report 2004-1380, Abs. p. 13.

Faux, R.N., Lachowski, H., Torgersen, C.E., and Boyd, M.S., 2001, New approaches for monitoring stream temperature: Airborne thermal infrared remote sensing: U.S. Department of Agriculture Inventory and Monitoring Project Report, 29 p.

Katz, B.G., Hornsby, H.D., Bohlke, J.F., and Mokray, M.F., 1999, Sources and chronology of nitrate contamination in spring waters, Suwannee River Basin, Florida: U.S. Geological Survey Water-Resources Investigations Report 99-4252, 54 p.

Katz, B.G., and Raabe, E.A., 2005, Suwannee River Basin and Estuary: Integrated Watershed Science Program: U.S. Geological Survey Open-File Report 2005-1210, 20 p.

Montague, C.L., and Odum, H.T., 1997, Settings and functions, Chap. 1 of Coultas, C.L., and Hsieh, Y. (eds.), Ecology and Management of Tidal Marshes - A Model from the Gulf of Mexico: Delray Beach, FL, St. Lucie Press, p. 9-34. 
NOAA, 2006, NOAA Tides and Currents: Center for Operational Oceanographic Products and Services, http://tidesandcurrents.noaa.gov/

Orlando, S.P.J., Rozas, L.P., Ward, G.H., and Klein, C.J., 1993, Salinity characteristics of Gulf of Mexico estuaries: Silver Spring, MD, National Ocean Service, Strategic Environmental Assessments Division, v. 197, 1993 p.

Packard, J.M., and Wetterquist, O.F., 1986, Evaluation of manatee habitat systems on the northwestern Florida coast: Coastal Zone Management Journal, v. 14, no. 4, p. 279-310.

Pride, R.W., and Crooks, J.W., 1962, The drought of 1954-56, its effect in Florida's surface water resources: Florida Geological Survey Report of Investigation, no. 26, 65 p.

Raabe, E.A., and Stumpf, R.P., 1996, Monitoring tidal marshes of Florida's Big Bend: Regional variations and geologic influences: U.S. Geological Survey Open-File Report 96-35 with 4 color plates and map insert, 1:500,000, 9 p.

Rauste, Y., Herland, E., Frelander, H., Soini, K., Kuoremaki, T., and Ruokari, A., 1997, Satellitebased forest fire detection for fire control in boreal forests: International Journal of Remote Sensing, v. 18, no. 12, p. 2641-2656.

Roseen, R.M., Brannaka, L.K., Ballestero, T.P., 2002, Nutrient loading from groundwater and its role in TMDLs: American Society of Agricultural and Biological Engineers, Conference, Fort Worth, Texas, USA, p. 262-267.

Rupert, F.R., 1988, Geology and geomorphology of Levy County, Florida: U.S. Geological Survey Open-File Report, no. 19, 18 p.

Rupert, F.R., 1991, Geology and geomorphology of Dixie County, Florida: U.S. Geological Survey Open-File Report, no. 45, 6 p.

Sams, J.I. III, and Veloski, G.A., 2003, Evaluation of airborne thermal infrared imagery for locating mine drainage sites in the Lower Kettle Creek and Cooks Run Basins, Pennsylvania, USA: Mine Water and the Environment, v. 22, no. 2, p. 85-93.

Scott, T.M., 2006, Florida's Springs in Jeopardy: Geotimes, http://www.geotimes.org/may02/feature springs.html

Shaban, A., Khawlie, M., Abdallah, C., and Faour, G., 2005, Geologic controls of submarine groundwater discharge: Application of remote sensing to north Lebanon: Environmental Geology, v. 47 no. 4, p. 512-522.

Siegel, E.M., Weisberg, R.H., Donovan, J.C., and Cole, R.D., 1996, Physical factors affecting intrusions in wetlands: The Suwannee River Estuary: University of South Florida, St. Petersburg, FL, Department of Marine Science, 127 p.

Spechler, R.M., 1996, Detection and quality of previously undetermined Floridian aquifer system discharge to the St. Johns River, Jacksonville to Green Cove Springs, northeastern Florida: U.S. Geological Survey Water-Resources Investigations Report 95-4257, 29 p.

Spechler, R.M., 2001, The relation between structure and saltwater intrusion in the Floridian aquifer system, Northeastern Florida: U.S. Geological Survey Water-Resources Investigations Report 01-4011, p. 25-29.

SRWMD (Suwannee River Water Management District), 2007, Technical Information about springs. http://www.srwmd.state.fl.us/water+data/springs/technical+info.htm

Stumpf, R.P., and Haines, J.W., 1998, Variations in tide level in the Gulf of Mexico and implications for tidal wetlands: Estuarine and Coastal Shelf Science, v. 46, no. 2, p. 165-173.

Tcherepanov, E.N., Zlotnik, V.A., and Henebry, G.M., 2005, Using Landsat thermal imagery and GIS for identification of groundwater discharge into shallow groundwater-dominated lakes: International Journal of Remote Sensing, v. 26, no. 17, p. 3649-3661.

Tillis, G.M., 2000, Flow and salinity characteristics of the Upper Suwannee River Estuary, Florida: U.S. Geological Survey Water-Resources Investigations Report 99-4268, 40 p. 
Torgensen, C.E., Faux, R.N., McIntosh, B.A., Poage, N.J., and Norton, D.J., 2001, Airborne thermal remote sensing for water temperature assessment in rivers and streams: Remote Sensing and Environment, v. 76, p. 386-398.

Torgensen, C.E., Price, D.M., Li, H.W., and McIntosh, B.A., 1995, Thermal refugia and chinook salmon habitat in Oregon: Applications of airborne thermal videography, in Proceedings of the $15^{\text {th }}$ Biennial Workshop on Color Photography and Videography, Mausel, P. (ed.), American Society for Photogrammatry and Remote Sensing, Conference in Terra Haute, IN, p. 167-171.

Vanek, V., and Lee, D.R., 1991, Mapping submarine groundwater discharge areas-an example from Laholm Bay, southwest Sweden: Limnology and Oceanography, v. 36, no. 6, p. 1250-1262.

Verimap, 2005, Suwannee River project final report: VeriMap PLUS Inc., 30 p. www.verimap.com.

Vernon, R.O., 1951, Geology of Citrus and Levy Counties, Florida: Forida Geological Survey Bulletin, no. 33, 256 p.

White, W.A., 1958, Some geomorphic features of Central Peninsular Florida: Florida Geological Survey Geological Bulletin, no. 41, 92 p.

Wolfe, S.H., 1990, An ecological characterization of the Florida springs coast: Pithlachascotee to Waccasassa Rivers: U.S. Fish and Wildlife Service Biological Report, v. 90, no. 21, 323 p.

Wolfe, S.H., and Wolfe, L.E., 1985, The ecology of the Suwannee River Estuary: An analysis of ecological data from the Suwannee River Water Management District study of the Suwannee River Estuary, 1982-1983: Florida Department of Environmental Regulation Technical Report, $118 \mathrm{p}$. 